\title{
Study on the KSFs of TTQS introduction in international hotels in Taiwan
}

\author{
Ying-Chang Chen ${ }^{\mathrm{a}}$ \\ Graduate School of Health Industry Management, Ching Kuo Institute of Management and Health, Keelung City \\ 20301, Taiwan
}

\begin{abstract}
This study explores the KSFs of TTQS, as introduced in international hotels in Taiwan. The method to carry out this study was using a survey AHP method. The findings of this study are, as follows: (1) Order of importance of the four dimensions: organizational management, training design, training execution, and result assessment, shows that when introducing TTQS, tourist hotels must first focus on reforming the organizational system. They should change the previous model to authorize training of the operational department. The training department should not play a passive role, and must establish a systematic training model with documents to dominate, as well as assist and audit training operations. (2) Among the 19 key factors of the sub-dimensions, the top 5 are high-ranking supervisors' high degree of support and participation, TTQS knowledge of persons in charge, connection between target members' and organizational needs, specific training goals before training, and regular training organization experience before introduction of TTQS. Based on the order, "high-ranking supervisors' support and participation" is the most important factor for organizations to introduce the TTQS system.
\end{abstract}

\section{Research background and motives}

On March 7, 2013, the World Economic Forum (WEF) announced the Travel \& Tourism Competitiveness Report 2013. Taiwan was listed at the Top 33 among 140 countries It demonstrates the performance of Taiwan regarding policies of the tourism industry and promotion of tourism. Since 2009, the Executive Yuan has implemented economic policies, such as six major new industries and ten key service industries, which include a tourism excellence project. Ten key service industries refer to the internationalization of food and exhibition industries. In addition, according to the statistics of the Tourism Bureau, in 2012, the number of tourists in Taiwan grew significantly, and surpassed 7.3 million person-times. The foreign exchange of tourism reached 340 billion NTD and the result was impressive[1].

Based on ISO10015, Investors in People (IIP) of Britain, occupational training policies of Europe, active occupational training policies of Australia, and challenges encountered by Taiwan regarding a global knowledge economy society, in 2005, the Workforce Development Agency established the "Taiwan TrainQuali Scorecard", which was then renamed as the Taiwan TrainQuali System (TTQS),

\footnotetext{
${ }^{\mathrm{a}}$ Corresponding author : proteus5520@gmail.com
} 
in order to match the training management of enterprises, organizations, and training institutions in Taiwan, enhance the connection between training quality and the world, reinforce the professional competence of human resources training and development of the service industry, and strengthening labor force and national competitiveness. However, regarding the type of industry, in 2012, only 7 international hotels applied for the project. This demonstrates that few tourist hotels participated in and passed evaluation.

The research purposes are shown, as follows:

1. To recognize previous educational training and motivation to introduce TTQS in international hotels.

2. To analyze KSFs of TTQS introduced in international hotels.

3. To construct items of KSFs of TTQS introduced in international hotels.

4. To decide the relative weights of KSFs of TTQS introduced in international hotels.

\section{Literature review}

\subsection{Educational training system of international hotels}

In recent years, the development of international hotels is vigorous, thus, the labor force must increase in order to balance supply and demand in the labor market. International hotels in the past encountered various problems, such as, a lack of a labor force, a high turnover rate, and employees' poor performance, most of which was due to poor human resources development, meaning they should improve the practice of educational training[2]. Some scholars have suggested that currently, educational training of international hotels is mostly based on apprenticeships, where experienced employees instruct freshmen or offer courses designed for the immediate issues of business development. These courses are not regular and are not necessarily in demand by employees in different departments[3]. However, complete pre-service training and on-the-job training will enhance employees' work efficiency, facilitate increased competence to become medium and high-ranking supervisors, lower work stress, and help employees develop careers. Therefore, systematic educational training should be designed by such systems[4].

Educational training in enterprises must be based on the effectiveness of output, and evaluation of educational training is the most common method to recognize overall training results. There are two main purposes: one is to continuously improve training processes and effects, and the other is to serve as reference for training decision-making. Assessment of training performance is a circular system with dimensions and steps. The purpose is to thoroughly recognize and reference current affairs to adjust previous methods in order to respond to changes of future markets and continuously pursue maximum effectiveness of educational training in enterprises[5]. According to research in recent years, educational training in hotels is based on employees' organizational commitment, and it considers the effects of employees' emotions and affections. Hence, educational training in hotels can be regarded as a multi-dimensional framework, including training motivation, training acquisition, training benefit, and training support. The results demonstrated that all such measures positively influence organizational commitment[6].

\subsection{TTQS (Talent Quality-management System)}

Vocational training enhances the number of courses and strengthens training quality. In Britain, the policy of training quality assessment is based on the WTO ISO10015 system and Investment in People (IIP). Since 2005, in order to reinforce the quality and performance of occupational training, the Taiwanese government established the "Taiwan TrainQuali Scorecard" to enhance effective national human capital investment, and strengthen human resources competitiveness and the results of occupational training. In 2013, in order to enhance the overall organizational competence of occupational training units and increase talent development and investment, the original name was 
changed to TTQS (Talent Quality-management System). TTQS was established upon ISO 10015 and IIP. The purpose is to enhance national talent capital and promote business and professional occupational training institutions. Hence, three objectives are developed: (1) corresponding assessment; (2) differential assessment; (3) connection between training performance and organizational development goals[7]. According to the three objectives, the TTQS classifies the training processes of PDCA of ISO 10015 into five circular and associated dimensions (see Figure 1). These five dimensions are Plan, Design, Do, Review, and Outcome (PDDRO). According to the research of scholars and the Business Training Network, the meanings of PDDRO are as shown in Figure 1[8-10].

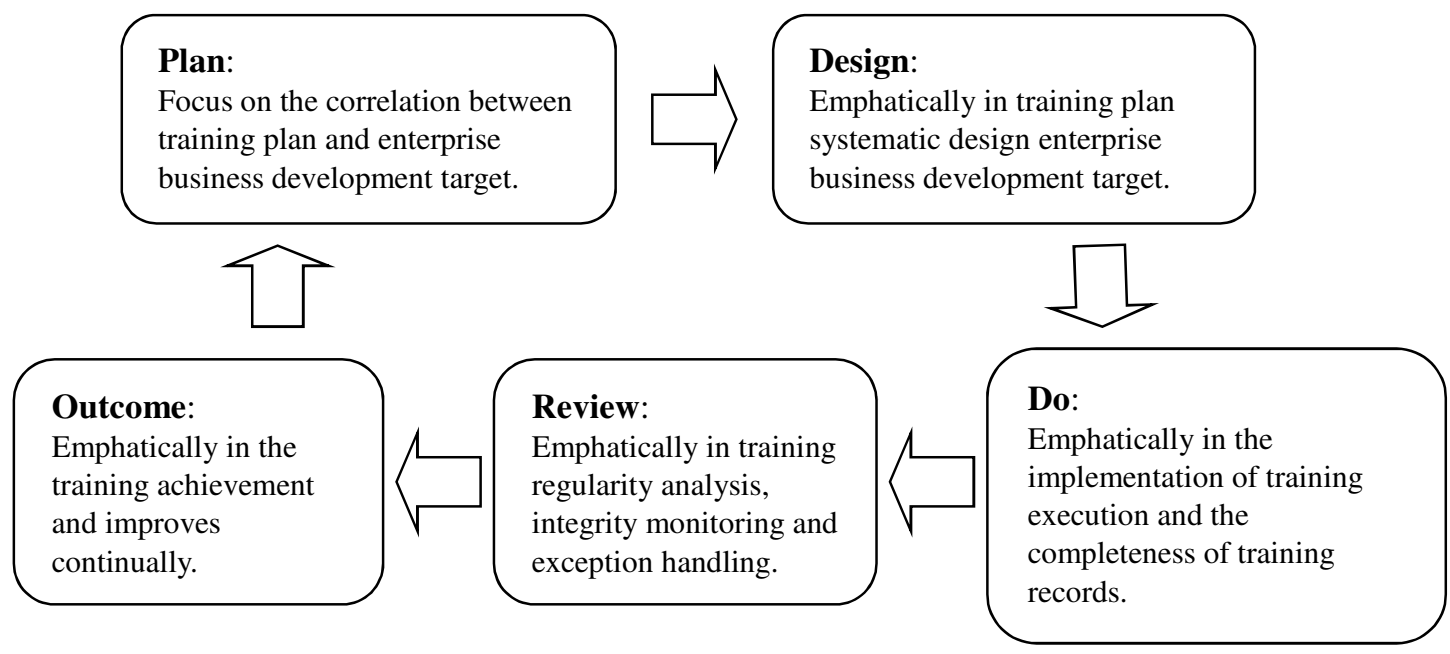

Figure 1. Five circular dimensions of TTQS.

\subsection{KSFs (Key Success Factors)}

KSFs appeared first in "Management Information Crisis", as published by Daniel in 1961. The success factors are defined, as follows: it is the work which should be excellent in order to be successful. Most industries have 3 6 success factors, and in order to be successful, enterprises must have excellent performance in these key factors. Hence, key success concepts become the important principles of the design of an information system.

KSFs are usually adopted when studying the relationship between industrial characteristics and organizational strategy. Aaker (1984) suggested that KSFs are the most important competitive advantages, assets, and techniques of enterprises, and they can be the base of competition[11]. The advantages of successful enterprises must be based on the KSFs of the industry. When an enterprise controls the KSFs of an industry, it will establish sustainable competitive advantages. Therefore, once organizations master certain fields and achieve prominent competence in comparison to others, they will have relative success factors in industrial environment. According to the research of Alazmi and Zairi[3], for enterprises, satisfying result in certain fields will guarantee successful performance. These activities are KSFs. Brotherton, Heinhuis, Miller, and Modema (2002) suggested that in order to completely accomplish an objective, enterprise should first establish KSFs[12]. According to Eindt, Jeffcoate, and Chappell (2002), in limited fields, variables of satisfying results that guarantee organizational success are KSFs[13]. Based on the views of previous scholars, KSFs are the key factors that enterprises must consider during industrial analysis. Successful enterprises usually are advantageous in the fields of KSFs, and when they seize competitive advantages in industry, operations will be sustainable.

Based on the definitions of scholars and related literature review, Chen (2011) suggested the following characteristics of KSFs: (1) KSFs change with time; (2) KSFs are different for different 
subjects of industry, goods, and markets; (3) KSFs will change with life cycle; (4) KSFs should be based on future trends[14]. Therefore, when studying KSFs, managers should consider the characteristics of the industry, as well as different times or life cycles of products, in order to obtain competitive advantages. Ho (1990) suggested that four methods are commonly adopted to confirm the number of KSFs, including regression analysis, factor analysis, Delphie, and AHP. AHP is the most common[15].

\section{Research method}

\subsection{Research process}

The research process is as shown in Figure 2. First, by collection, analysis, and review of primary literatures, the researcher generalized the analysis of KSFs in TTQS introduced in international hotels. Based on the theory, this study developed the dimensions and principles of a case interview outline. Secondly, it selected and invited the human resource supervisors of international hotels and TTQS assessment members. Based on the previous dimensions, it discussed and consulted experts regarding the questionnaire in order to validate the propriety of dimensions and adjust them to develop the final AHP questionnaire. Secondly, it selected the subjects. After retrieving the questionnaires, the researcher calculated the order of the factors, according to Expert Choice, to lead to the research results.

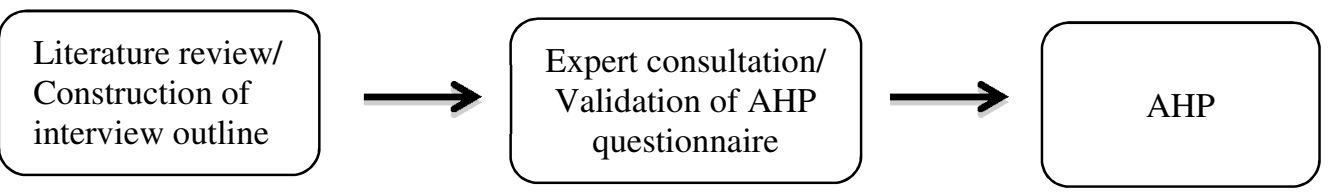

Figure 2. Research process

\subsection{Subjects of experts}

The interviews lasted from March 20 to June 10, 2014. There were ten subjects, including 3 human resource supervisors that have participated in TTQS assessment in international hotels, and 7 assessment members or consultants of international hotels. Among the assessment members, 2 have backgrounds in the food and hospitality industry.

\subsection{AHP questionnaire distribution and effectiveness analysis}

By literature review and hierarchical framework of interview results, this study established the AHP questionnaire. The purpose was to determine the weights and rankings of KSFs of TTQS introduced in international hotels. The questionnaires were distributed from July 1 to November 10, 2014. Regarding the number of questionnaires distributed, according to the suggestion of Saaty and Forman (1996), when dealing with decision-making by AHP, the number of experts should few, 5 15 is appropriate[16]. Therefore, in this study, questionnaires were distributed to 6 human resource supervisors that have participated in TTQS assessment in tourist hotels, and 9 assessment members or consultants of international hotels. A total of 15 questionnaires were distributed and return rate was $100 \%$. The figures obtained from questionnaires were analyzed by Expert Choice. The valid return rate was $100 \%$, and all questionnaires were tested by C.I. and C.R. Therefore, in this study, there are 15 valid questionnaires, and the screening principle is shown, as follows:

(1) C.I.: C.I. $>0.1$

(2) C.R.: C.R.>0.1 


\section{Data analysis and results}

\subsection{Literature review and questionnaire development}

Table 1. KSFs of ISO10015 or TTQS introduced in enterprises.

\begin{tabular}{|c|c|c|}
\hline Researchers & KSFs of ISO 10015 or TTQS introduced in enterprises & Research Method \\
\hline Wang(2006) & $\begin{array}{l}\text { 1. HRD personnel should possess more knowledge and skills related } \\
\text { to the process of training design } \\
\text { 2. Support of management }\end{array}$ & Observation research \\
\hline $\operatorname{Lin}(2006)$ & $\begin{array}{l}\text { 1. Stakeholders' active participation } \\
\text { 2. Investigation of demands of business training } \\
\text { 3. Construction standard of employees' competence } \\
\text { 4. Planning and design competence of training course } \\
\text { 5. Connection between training process and business performance }\end{array}$ & Observation research \\
\hline $\begin{array}{l}\text { Lin, Chin, Huang, } \\
\text { Huang } \\
\text { (2007) }\end{array}$ & $\begin{array}{l}\text { 1. Support of management } \\
\text { 2.Employees' understanding and participation in the overall strategy } \\
\text { of educational training of the company } \\
\text { 3. Stakeholders' active participation } \\
\text { 4. Continuous improvement } \\
\text { 5. Systematic database }\end{array}$ & $\begin{array}{l}\text { SPSS } \\
\text { statistics }\end{array}$ \\
\hline Peng(2007) & $\begin{array}{l}\text { 1.High-ranking supervisors' participation } \\
\text { 2. Educational training plan should match operational strategy } \\
\text { 3. Completeness of documents and records } \\
\text { 4. Construction of standard business processes and training system } \\
\text { 5. Person in charge must have complete competence and skill of } \\
\text { competence analysis and design of training courses } \\
\text { 6. Setting of KPI indicators } \\
\text { 7. Training upon salary, examination, or promotions } \\
\end{array}$ & Observation research \\
\hline \begin{tabular}{|l|} 
Chen \\
$(2008)$
\end{tabular} & $\begin{array}{l}\text { 1. Support and determination of high-ranking supervisors } \\
\text { 2. All employees' participation and identification } \\
\text { 3. Educational training and employee quality } \\
\text { 4. Validation and assistance of guidance unit } \\
\text { 5. Customer orientation and communication } \\
\text { 6. Usage of information system } \\
\text { 7. Precise planning and thorough execution } \\
\text { 8. Current system (such as ISO related system) and previous } \\
\text { successful experience } \\
\text { 9. Document control and writing } \\
\text { 10. Continuous improvement } \\
\text { 11. Confirmation of auditing and adjustment effect }\end{array}$ & Interview \\
\hline Huang(2009) & $\begin{array}{l}\text { 1. Support and determination of high-ranking supervisors } \\
\text { 2. Team members' execution ability of human capital } \\
\text { 3. Connection between training demands and organizational } \\
\text { performance } \\
\text { 4. Training result enhances organizational performance } \\
\text { 5. Project members have communication capacity } \\
\text { 6. Employees' learning and action plan before training } \\
\end{array}$ & $\begin{array}{l}\text { Analytic hierarchy } \\
\text { process (AHP) }\end{array}$ \\
\hline $\begin{array}{l}\text { Yeh and Tsai } \\
(2010)\end{array}$ & $\begin{array}{l}\text { 1. High-ranking supervisors' high commitment and active } \\
\text { involvement in IIP } \\
\text { 2. One professional human resource employee in the organization as } \\
\text { the key promoter of IIP } \\
\text { 3. Successful and in-depth strategy communication in the } \\
\text { organization } \\
\text { 4. Members have ownership and sense of belonging to the institution, } \\
\text { which effectively lowers employees' turnover rate } \\
\text { 5. Organization can transform IIP into important management tool of }\end{array}$ & Observation research \\
\hline
\end{tabular}




\begin{tabular}{|c|c|c|}
\hline & $\begin{array}{l}\text { organizational reform and implement it } \\
\text { 6. IIP system is further combined with organizational culture } \\
\text { 7. Organization has continuous improvement }\end{array}$ & \\
\hline $\begin{array}{l}\text { Pai and Kung } \\
\text { (2012) }\end{array}$ & $\begin{array}{l}\text { 1. Leaders participation, and implementation is from top to the } \\
\text { bottom in order to enhance the determination of introduction. } \\
\text { 2. Person in charge should have intention to learn knowledge related } \\
\text { to TTQS. } \\
\text { 3. Work Union should recognize market demand and communicate } \\
\text { with lecturers regarding the design of courses. } \\
\text { 4. Assistance from consultants of TTQS. }\end{array}$ & $\begin{array}{l}\text { Analytic hierarchy } \\
\text { process (AHP) }\end{array}$ \\
\hline Huang et al.(2013) & $\begin{array}{l}\text { 1. Support and determination of high-ranking supervisors } \\
\text { 2. Total employees' participation and identification } \\
\text { 3. Educational training and employee quality } \\
\text { 4. Validation and assistance of guidance unit } \\
\text { 5. Customer orientation and communication } \\
\text { 6. Usage of information system } \\
\text { 7. Precise planning and thorough execution } \\
\text { 8. Current system (such as ISO related system) and previous } \\
\text { successful experience } \\
\text { 9. Document control and writing } \\
\text { 10. Continuous improvement } \\
\text { 11. Confirmation of auditing and adjustment effect }\end{array}$ & \\
\hline
\end{tabular}

Table 2. Definitions and descriptions of key factors of TTQS introduced in tourist hotels.

\begin{tabular}{|c|c|c|c|}
\hline Ultimate goal & Level 1 & Code & Level 2 \\
\hline \multirow{19}{*}{$\begin{array}{l}\text { KSFs of TTQS } \\
\text { introduced in } \\
\text { international hotels }\end{array}$} & \multirow{6}{*}{$\begin{array}{c}\text { A. } \\
\text { Organizational } \\
\text { management }\end{array}$} & A1 & $\begin{array}{lllllll}\begin{array}{l}\text { High-ranking } \\
\text { participation }\end{array} & \text { supervisors' high degree } & \text { of } & \text { support and } \\
\end{array}$ \\
\hline & & A2 & $\begin{array}{l}\text { Active acquisition of TTQS related knowledge of persons in } \\
\text { charge }\end{array}$ \\
\hline & & A3 & $\begin{array}{l}\text { Regular training organization experience before introduction of } \\
\text { TTQS }\end{array}$ \\
\hline & & A4 & $\begin{array}{l}\text { High cognition of department supervisors regarding training } \\
\text { responsibility }\end{array}$ \\
\hline & & A5 & Complete documents related to training \\
\hline & & A6 & Assistance from consultants of TTQS \\
\hline & \multirow{6}{*}{$\begin{array}{l}\text { B. Training } \\
\text { design }\end{array}$} & B1 & $\begin{array}{l}\text { Connection between competence demand of different levels and } \\
\text { categories of posts of the course }\end{array}$ \\
\hline & & B2 & Specific training goals before practice of training \\
\hline & & B3 & Learners' recognition of course objectives before the course \\
\hline & & B4 & Department supervisors' participation in course design \\
\hline & & B5 & Lecturers' participation in course design \\
\hline & & B6 & $\begin{array}{l}\text { Connection between the demands of target learners and the } \\
\text { organization }\end{array}$ \\
\hline & \multirow{4}{*}{$\begin{array}{l}\text { C. Training } \\
\text { execution }\end{array}$} & $\mathrm{C} 1$ & $\begin{array}{l}\text { Offering a positive environment for course learning by persons in } \\
\text { charge }\end{array}$ \\
\hline & & $\mathrm{C} 2$ & Employees' learning and action plan before training \\
\hline & & $\mathrm{C} 3$ & $\begin{array}{l}\text { Complete training record by systematic administrative } \\
\text { management }\end{array}$ \\
\hline & & $\mathrm{C} 4$ & $\begin{array}{l}\text { Arrangement of assistants of courses in order to guarantee course } \\
\text { execution }\end{array}$ \\
\hline & \multirow{3}{*}{$\begin{array}{l}\text { D. Result } \\
\text { assessment }\end{array}$} & D1 & Complete review to continuously improve quality \\
\hline & & $\mathrm{D} 2$ & Setting of KPI indicators \\
\hline & & D3 & Training upon salary, examination, or promotions \\
\hline
\end{tabular}

Source: Compiled by this study

Results of data collection and literature of ISO10015 introduced in organizations, IIP of the U.K., and TTQS, are as shown in Table 1. Upon review of previous literature and key factors, regarding validity, 
before distributing questionnaires, this study authorized 3 human capital supervisors that participated in TTQS assessment, and 7 assessment members or consultants in international hotels, in order to examine the expert validity of the questionnaire. By interview or e-mail, this study deleted or added the descriptions of some items of the questionnaire. Finally four dimensions are developed: organizational management, training design, training execution, and result assessment (Level 1), including 19 sub-items (Level 2). The definitions and descriptions of KSFs are as shown in Table 2.

\subsection{Relative weights of KSFs}

By four dimensions, as obtained from previous interview results, including $16 \mathrm{KSFs}$, this study establishes the hierarchical structure of AHP and compares the relative weights in order to obtain the degrees of factors. The analytical results of the relative weights of the four dimensions, as well as the relative weights of the total KSFs, are as shown in Table 3. The results indicate $19 \mathrm{KSFs}$ in four dimensions. Based on the suggestions of Saaty and Forman (1996), inconsistency of each level is C.R. (Consistence Ratio). When C.R. is lower than 0.1, consistency is acceptable. This study conducts analysis by Expert Choice, and obtains C.R. $=0.017$ of total dimensions. The value is lower than 0.1; hence, the consistency of matrix is high[16].

Table 3. Relative weights of the four levels and sub-factors of KSFs of TTQS introduced in tourist hotels.

\begin{tabular}{|c|c|c|c|c|}
\hline $\begin{array}{l}\text { Ultimate } \\
\text { goal }\end{array}$ & Level 1 & Weight & Level 2 & Weight \\
\hline \multirow{19}{*}{\begin{tabular}{|c|} 
KSFs of \\
TTQS \\
introduced \\
in \\
international \\
hotels
\end{tabular}} & \multirow{6}{*}{$\begin{array}{c}\text { A. } \\
\text { organizational } \\
\text { management }\end{array}$} & \multirow{6}{*}{0.487} & $\begin{array}{l}\text { A1 High-ranking supervisors' high degree of support and } \\
\text { participation }\end{array}$ & 0.371 \\
\hline & & & $\begin{array}{l}\text { A2 Active acquisition of TTQS related knowledge of } \\
\text { persons in charge }\end{array}$ & 0.225 \\
\hline & & & $\begin{array}{l}\text { A3 Regular training organization experience before } \\
\text { introduction of TTQS }\end{array}$ & 0.127 \\
\hline & & & $\begin{array}{l}\text { A4 High cognition of department supervisors regarding } \\
\text { training responsibility }\end{array}$ & 0.108 \\
\hline & & & A5 Complete documents related to training & 0.046 \\
\hline & & & A6 Assistance from consultants of TTQS & 0.123 \\
\hline & \multirow{6}{*}{$\begin{array}{l}\text { B. training } \\
\text { design }\end{array}$} & \multirow{6}{*}{0.286} & $\begin{array}{l}\text { B1 connection between competence demand of different } \\
\text { levels and categories of posts of the course }\end{array}$ & 0.122 \\
\hline & & & B2 Specific training goals before practice of training & 0.257 \\
\hline & & & $\begin{array}{l}\text { B3 Learners' recognition of course objectives before the } \\
\text { course }\end{array}$ & 0.111 \\
\hline & & & B4 Department supervisors' participation in course design & 0.063 \\
\hline & & & B5 Lecturers' participation in course design & 0.081 \\
\hline & & & $\begin{array}{l}\text { B6 Connection between the demands of target learners and } \\
\text { the organization }\end{array}$ & 0.366 \\
\hline & \multirow{4}{*}{$\begin{array}{l}\text { C. training } \\
\text { execution }\end{array}$} & \multirow{4}{*}{0.127} & $\begin{array}{l}\text { C1 Offering a positive environment for course learning by } \\
\text { persons in charge }\end{array}$ & 0.243 \\
\hline & & & C2 Employees' learning and action plan before training & 0.288 \\
\hline & & & $\begin{array}{l}\text { C3 Complete training record by systematic administrative } \\
\text { management }\end{array}$ & 0.202 \\
\hline & & & $\begin{array}{l}\text { C4 Arrangement of assistants of courses in order to } \\
\text { guarantee course execution }\end{array}$ & 0.267 \\
\hline & \multirow{3}{*}{$\begin{array}{l}\text { D. result } \\
\text { assessment }\end{array}$} & \multirow{3}{*}{0.109} & D1 Complete review to continuously improve quality & 0.235 \\
\hline & & & D2 Setting of KPI indicators & 0.376 \\
\hline & & & D3 Training upon salary, examination, or promotions & 0.389 \\
\hline
\end{tabular}

Source: Compiled by this study 


\section{Conclusion and suggestions}

\subsection{Conclusions}

In conclusion, the researcher will first generalize the findings and results discussion. Based on the rankings of the relative weights of the sub-factors of the dimensions, this study develops a weight framework for KSFs of TTQS introduced in tourist hotels (Table 4), as follows:

Table 4. Ranking of weights of KSFs of TTQS introduced in tourist hotels.

\begin{tabular}{|c|c|c|c|c|c|}
\hline $\begin{array}{c}\text { Ultimate } \\
\text { goal }\end{array}$ & Level & Weight & Level 2 & Weight & $\begin{array}{c}\text { Rankin } \\
\mathrm{g}\end{array}$ \\
\hline \multirow{19}{*}{$\mid \begin{array}{l}\text { KSFs of } \\
\text { TTQS } \\
\text { introduced } \\
\text { in } \\
\text { internation } \\
\text { al hotels }\end{array}$} & \multirow{6}{*}{$\begin{array}{c}\text { A. } \\
\text { organizational } \\
\text { management }\end{array}$} & \multirow{6}{*}{0.478} & $\begin{array}{l}\text { A1 High-ranking supervisors' high degree of support and } \\
\text { participation }\end{array}$ & 0.371 & 1 \\
\hline & & & $\begin{array}{l}\text { A2 Active acquisition of TTQS related knowledge of } \\
\text { persons in charge }\end{array}$ & 0.225 & 2 \\
\hline & & & $\begin{array}{|lll|}\text { A3 Regular training organization experience before } \\
\text { introduction of TTQS }\end{array}$ & 0.127 & 3 \\
\hline & & & A6 Assistance from consultants of TTQS & 0.123 & 4 \\
\hline & & & \begin{tabular}{|l|} 
A4 High cognition of department supervisors regarding \\
training responsibility
\end{tabular} & 0.108 & 5 \\
\hline & & & A5 Complete documents related to training & 0.046 & 6 \\
\hline & \multirow{6}{*}{$\begin{array}{l}\text { B. training } \\
\text { design }\end{array}$} & \multirow{6}{*}{0.286} & $\begin{array}{l}\text { B6 Connection between the demands of target learners and } \\
\text { the organization }\end{array}$ & 0.366 & 1 \\
\hline & & & B2 Specific training goals before practice of training & 0.257 & 2 \\
\hline & & & $\begin{array}{l}\text { B1 Connection between competence demand of different } \\
\text { levels and posts of the course }\end{array}$ & 0.122 & 3 \\
\hline & & & \begin{tabular}{|l|}
$\begin{array}{l}\text { B3 Learners' recognition of course objectives before the } \\
\text { course }\end{array}$ \\
\end{tabular} & 0.111 & 4 \\
\hline & & & B5 Lecturers' participation in course design & 0.081 & 5 \\
\hline & & & B4 Department supervisors' participation in course design & 0.063 & 6 \\
\hline & \multirow{4}{*}{$\begin{array}{l}\text { C. training } \\
\text { execution }\end{array}$} & \multirow{4}{*}{0.127} & C2 Employees' learning and action plan before training & 0.288 & 1 \\
\hline & & & \begin{tabular}{|l|l|}
$\begin{array}{l}\text { C4 Arrangement of assistants of courses in order to } \\
\text { guarantee course execution }\end{array}$ \\
\end{tabular} & 0.267 & 2 \\
\hline & & & $\begin{array}{l}\text { C1 Offering a positive environment for course learning by } \\
\text { persons in charge }\end{array}$ & 0.243 & 3 \\
\hline & & & $\begin{array}{l}\text { C3 Complete training record by systematic administrative } \\
\text { management }\end{array}$ & 0.202 & 4 \\
\hline & \multirow{3}{*}{$\begin{array}{l}\text { D. result } \\
\text { assessment }\end{array}$} & \multirow{3}{*}{0.109} & D1 Training upon salary, examination, or promotions & 0.389 & 1 \\
\hline & & & D2 Setting of KPI indicators & 0.376 & 2 \\
\hline & & & D3 Complete review to continuously improve quality & 0.235 & 3 \\
\hline
\end{tabular}

Source: Compiled by this study

\subsubsection{Importance rankings of the four dimensions}

According to the analytical results of the dimensions at the first level, the rankings of importance are, as follows: organizational management (0.478), training design (0.286), training execution (0.127), and results assessment (0.109). The previous four dimensions have importance ranking of KSFs of 
TTQS introduced in tourist hotels. The results show that according to all experts, organizational management is the priority of KSFs of TTQS introduced in tourist hotels. The result matches the findings of several scholars[9, 17-20]. Based on the previous result, when introducing TTQS, tourist hotels must first focus on reform of the organizational system, and change the previous model to authorize training for the business department. The training organization department should not be passive, and must establish a systematic training model with documents in order to dominate, assist, and audit training.

\subsubsection{Analytical results of hierarchical weights of sub-factors}

The second level includes 19 sub-dimensions. When analyzing weights, the researcher divides them into hierarchical weights and total weights. Hierarchical weights mean the relative importance of plans in the next level, as based upon the standard of the previous level, which shows the importance of plans, as based upon the criteria, meaning the prior vector upon the criteria of the previous level. Therefore, the sum of the hierarchical values upon the same criterion must be 1.0.

Regarding organizational management, the weight of high-ranking supervisors' high support and participation (0.371) is the highest; followed by: active acquisition of TTQS related knowledge of persons in charge $(0.225)$, regular training organization experience before introduction of TTQS (0.127), assistance from consultants of TTQS (0.123), high cognition of department supervisors regarding training responsibility (0.108), and complete documents related to training (0.046). Based on research, TTQS is systematic educational training, and the introduction of TTQS means to introduce new ISO. Reform is required in organizational behavior. All organizational reform requires high-ranking supervisors' significant support and participation, and the results of this study indicate the same. In addition, understanding of TTQS knowledge of persons in charge is second. When introducing TTQS, they should not lack agreement or understanding. Therefore, regarding communication with high rank or introduction to employees, persons in charge should understand more about TTQS. Therefore, TTQS can be integrated with an original training model in order to avoid the obstacles of the introduction of a new system. In addition, when introducing the TTQS system, the assistance of a TTQS consultant and previous training of organization experience will accelerate the introduction.

Regarding training design, the weight of the connection between the demands of target learners and the organization $(0.366)$ is the highest, followed by: specific training objectives before training (0.257), connection between competence demand of different levels and posts of the course (0.122), learners' recognition of course objectives before class (0.111), lecturers' participation in course design (0.081), and department supervisors' participation in course design (0.063). Based on the results, organizational demand is the priority of training for organizations, meaning the right learners and the right courses are the most important. Therefore, connection between the demands of target learners and the organization, specific training objectives before training, and connection between competence demand of different levels and posts of the course are the top 3 of the training design. In addition, in order to meet the competence gap of the business department by training, we suggest that lecturers and department supervisors can participate in course design.

Regarding training execution, the weight of the establishment of employees' learning and action plans before training (0.288) is the highest, followed by: Arrangement of assistants of courses in order to guarantee course execution (0.267), offering a positive environment for course learning by persons in charge (0.243), and complete training record by systematic administrative management (0.202). Based on the results, the establishment of employees' learning and action plan before training is the most important. This is consistent with the connection with organizational demand in training design. Secondly, arrangement of assistants in the course, as well as offering good training locations, will result in successful training.

Regarding the results assessment, the weight of training upon salary, examination, or promotions (0.389) is the highest, followed by: setting of KPI indicators (0.376) and complete review to continuously improve quality (0.235). According to the results, training upon salary, examination, or 
promotion will enhance the learners' training motivation. In addition, by setting KPI indicators, training and business departments will have a reference, and learn how to arrange a proper labor force and time. However, the results demonstrate that the score of continuous quality improvement by complete review is the lowest, which shows that enterprises pay attention to short-term effectiveness of training, and is the gap with TTQS that focuses on continuous improvement.

\subsubsection{Analytical results of total weights of sub-factors}

Table 5. Overall relative weights and rankings of KSFs of TTQS introduced in international hotels.

\begin{tabular}{|c|c|c|}
\hline KSFs of TTQS introduced in international hotels & Overall weights & Ranking \\
\hline A1 High-ranking supervisors' high degree of support and participation & 0.177 & 1 \\
\hline A2 Active acquisition of TTQS related knowledge of persons in charge & 0.108 & 2 \\
\hline B6 Connection between the demands of target learners and the organization & 0.105 & 3 \\
\hline B2 Specific training goals before practice of training & 0.074 & 4 \\
\hline A3 Regular training organization experience before introduction of TTQS & 0.061 & 5 \\
\hline A6 Assistance from consultants of TTQS & 0.059 & 6 \\
\hline $\begin{array}{l}\text { A4 High cognition of department supervisors regarding training } \\
\text { responsibility }\end{array}$ & 0.052 & 7 \\
\hline D1 Training upon salary, examination, or promotions & 0.042 & 8 \\
\hline D2 Setting of KPI indicators & 0.041 & 9 \\
\hline C2 Employees' learning and action plan before training & 0.037 & 10 \\
\hline $\begin{array}{l}\text { B1 Connection between competence demand of different levels and posts } \\
\text { of the course }\end{array}$ & 0.035 & 11 \\
\hline $\begin{array}{l}\text { C4 Arrangement of assistants of courses in order to guarantee course } \\
\text { execution }\end{array}$ & 0.034 & 12 \\
\hline B3 Learners' recognition of course objectives before the course & 0.032 & 13 \\
\hline $\begin{array}{l}\mathrm{C} 1 \text { Offering a positive environment for course learning by persons in } \\
\text { charge }\end{array}$ & 0.031 & 14 \\
\hline C3 Complete training record by systematic administrative management & 0.026 & 15 \\
\hline D3 Complete review to continuously improve quality & 0.026 & 16 \\
\hline B5 Lecturers' participation in course design & 0.023 & 17 \\
\hline A5 Complete documents related to training & 0.022 & 18 \\
\hline B4 Department supervisors' participation in course design & 0.018 & 19 \\
\hline
\end{tabular}

Source: Compiled by this study

Total weights mean relative importance at the same level regarding the previous level of the upper level. It refers to the prior vector of the total concern of the total objective. Hence, the sum of all criteria of the next level or prior weights of the plan should be 1 . Table 5 shows total relative weights and ranking of the sub-dimensions at the second level. Based on Table 5, the top 5 key factors among the 19 sub-dimensions at the second level are high-ranking supervisors' high degree of support and participation (0.177), active acquisition of TTQS knowledge by persons in charge (0.108), connection between the demands of target learners and the organization (0.105), specific training objectives before training (0.074), and regular training organization experience before introduction of TTQS (0.061). The rankings show that "high-ranking supervisors' support and participation" is the most important factor of organizations when introducing the TTS system. This result matches the findings of many scholars regarding the key factors of ISO 9001 or ISO10015 introduced by enterprises. In addition, recognition of the TTQS knowledge of persons in charge is the second, which matches the sixth indicator "capacity of persons in charge" in the TTQS list of the business version. 


\subsection{Suggestions}

Based on previous results, this study proposes the following suggestions regarding TTQS introduced in international tourist hotels:

(1) High-ranking supervisors must have a high degree of support and participation to result in effective introduction of the training system.

(2) Person in charge of training must enhance personal competence related to TTQS or human resources, which will enhance implementation of the TTQS project, completeness of the training design, and fulfillment of training execution and effectiveness.

(3) The training design should be based on training objectives upon organizational demand. Before training, the members should recognize the training purpose.

(4) When training effectiveness is based on salary, examination, or promotion, it can effectively increase training motivation.

(5) TTQS consultation is a useful resource, and its effective use will accelerate the introduction of the TTQS training system.

\section{References}

1. Tourism Bureau, MOTC Administrative Information System, Monthly Report on Tourist Hotel Operations in Taiwan (Tourism Bureau, Taiwan, 2012)

2. R.C. Mill and A.M. Morrison, The Tourism System: A Introduction Text (Englewood Cliffs, USA, 1985)

3. M. Alazmi and M. Zairi, Total Quality Management \& Business Excellence, 14 (2), 199-204 (2003)

4. Y.Y. Lin, Master's thesis, A study of the relationship between employees' educational training and job satisfaction in international tourist hotels in Taiwan (Kaohsiung, Taiwan, 2009)

5. L.L. Wang, Master's thesis, The influence of training on organizational performance: empirical samples from financial industry in Taiwan (Kaohsiung, Taiwan, 2006)

6. C. Bulut and O. Culha, Int. J. Training and Development, 14 (4), 309-322 (2010)

7. Business Training Network, Introduction of project of training quality system, Retrieved from: http://ttqs.evta.gov.tw/ (2013)

8. S.Y. Huang, Master's thesis, KSFs study on TTQS introduced in enterprises (Chia-yi county, Taiwan, 2009)

9. T.S. Huang and J.Y. Cai, East-Asia Rev., 467, 65-80 (2010)

10. J.S. Lin, Employment Security, 5 (2), 44-51 (2006)

11. A. Aaker, Strategic Market Management (New York, USA, 1984)

12. B. Brotherton, E. Heinhuis, K. Miller, et al., Journal of Services Research, 2, 47-78 (2002)

13. Eindt, Jeffcoate, External Relationships and the Small Business: A Review of Small Business Alliance and Network Research (Chappell, Mexico, 2002)

14. C.T. Chen, Master's thesis, An empirical research of the key success factors for chain administration- english supplements school industry as an example (Taipei City, Taiwan, 2011)

15. Y.C. Ho, Practical Marketing Management (Hwa Tai, Taiwan, 1990)

16. T.L. Saaty and E.H. Forman, The Hierarchon: A Dictionary of Hierarchies (Pittsburgh, USA, 1996)

17. W.T. Lin, R.S. Chin, M.R. Huang, and C.C. Huang, The 43th Annual Meeting of Chinese Society for Quality and $13^{\text {th }}$ National Quality Management Conference (Hsinchu, Taiwan, 2007)

18. C.W. Yeh and S.T. Tsai, Report on demonstration of IIP international human resource equality system (Workforce Development Agency, Taiwan, 2010)

19. Tourism Bureau, MOTC Administrative Information System, Monthly Report on Tourist Hotel Operations in Taiwan (Tourism Bureau, Taiwan, 2013)

20. C.C. Huang, M.C. Lin, S.H. Lin, M.F. Huang, and Y.H. Wang, Innovation and Operational Management, 4 (1), 15-28 (2013) 